\section{ELECTRONS AND MATTER.}

THE inaugural address on "Electronen en Materie," delivered by Prof. C. H. Wind upon taking the chair of mathematical physics and theoretical mechanics at the University of Utrecht on February 20 of this year, has lately been published (Levden: A. W. Sijthoff) Beginning with a brief account of the gradual development of the conception of electrons, mainly through the works of H. A. Lorentz, and of its sudden corroboration after the discoveries made by Zeeman and Röntgen, the address goes on with an exposition of the notions of ether, electric displacement, electrons, and magnetic force in their present form, and traces the way to the idea of an electromagnetic mass of the electrons.

The measurements made by Kauffmann, though showing that these particles of matter probably do not possess any mass besides this electromagnetic one, of course do not prove that the same should be the case with all other particles of matter in our universe, as Wien had suggested. Yet they make this suggestion-the basis of what the author calls an electron theory a outrance-to some extent a plausible one. Several of the brilliant and fascinating views which this ultimate theory opens having been expounded by $\mathrm{Mr}$. Balfour in his presidential address at the Cambridge meeting of the British Association, the present author directs attention to those concerning the structure of atoms, mechanism of radiation, and origin of chemical differences. He also enters into some more details, and assuming for a while that an atom of hydrogen consists of a single positive and a single negative electron, calculates that in this system the two components would be separated by a distance perhaps 100,000 times greater than the diameter of the largest of them, and that there must be stored up in the atoms constituting one gram of hydrogen an amount of energy equivalent to that required by a mail steamer to cross the Atlantic ten times.

Poincaré has raised several serious objections against the theory. Some of these relate to the temperate electron theory only, and lose their weight as soon as the ultimate theory is adopted. To take an example. Poincaré does not feel satisfied with the changes of length in solid bodies owing to their motion through ether, as suggested by Lorentz and by Fitzgerald in order to explain the result of Michelson's experiments. Lorentz himself, however, has already shown that this hypothesis, though appearin rather bold at first sight, becomes plausible as soon as molecular forces and masses are supposed to be in the same way as electromagnetic ones affected by a translation through ether; and it is clear that this supposition is involved in that of all matter consisting of electrons, which therefore at once clears the way.

The second category of objections, those arising from the dependency of electromagnetic mass upon velocity and direction of motion, from so many instances of unequal action and reaction, from the violation even of the law of inertia, whenever electrons move with a higher speed than light, are, on the other hand, most serious in the light of the ultimate electron hypothesis, whereas the temperate theory has a way left open to dispose of them. The latter theory, indeed, does not deny the existence of matter apart from electrors and considers electromagnetic mass as something se:sndary. By assuming as constituents of ether hidfe:: inatter, obeying the classical principles just as well as ordinary or coarse niatter this theory will be able to accourt for every apparent deviation from the principles which by nathematical reasoning should be deducted as occurrins in ccarse matter.

But if by progress of experiment and theory the electron hypothesis in its ultimate form should continue to gain ground, if it should finally prove unavoidable to accept the view that matter consists entirely of electrons, then mass and momentum would cease to be what they are now in our ideas, quantities strictly invariable. There is no. denying that this would involve a serious change of our general conception of nature. For the predilection and confidence with which science has for centuries been aiming at a description of the physical universe in terms only of matter and motion were based chiefly-though half unconsciously - on the idea of mass and momentum being invariable elements of nature, images or pictures of inNo. I 875 , voL. 72] variable elements of reality itself. Now this idea, si fundamental to our whole mechanical conception of nature, would shrink into an illusion in the light of the new theory. Of course, there would be a great advantage also. Whereas it scems now almost hopeless to involve electromagnetic phenomena in a description in terms only of matter and motion, the unity desired in our picture of the physical world would then be secured by putting it in terms of electrons and motion.

\section{UNIVERSITY AND EDUCATIONAL INTELLIGENCE.}

WE learn from Science that an anonymous gift has been made to the Lebanon Valley College, Annville, Pa., of a hall of science to cost $16,000 l$.

Mr. F. R. B. Watson has been appointed assistant lecturer and demonstrator in engineering at the Merchant Venturers' Technical College, Bristol.

A Reuter message from New York states that the American General Education Board has received from Mr. John Rockefeller cheques to the amount of $2,000,000 l$. , in pursuance of his promise last June to give that amount in cash or securities for the endowment of higher education.

A PRIZE of $50 l$. out of the Gordon-Wigan fund will be awarded at the end of the Easter term, I906, for a research in chemistry, of sufficient merit, carried out in the University of Cambridge. The research may be in any branch of chemistry. The dissertation, with the details of the research, must be sent to the professor of chemistry not later than the division of the Easter term, rgo6.

THE year-book of the faculty of engineering of the University of Liverpool (1905-6) shows that the courses of study are so arranged as to afford a general scientific training for those intending to become engineers. The honours course affords opportunities for specialisation in a selected branch of the profession. The university training, which extends over three years, is preliminary to or supplementary of pupilage under an engineer or apprenticeship with an engineering firm.

IT is announced in Science that the University of Pennsylvania will receive $12,000 l$. from the estate of the late Prof. Maxwell Sommerville, who held a chair of archæology in the university. President Thwing, of Western Reserve University, we learn from the same source, has announced that $\mathrm{Mr}$. Andrew Carnegie has given 50ool. towards the establishment of a fund of $20,000 l$. for the endowment of a chair of political economy at Western Reserve University, to bear the name of the late Senator Hanna.

TuE Engineering and Mining Journal publishes the presidential address delivered by Mr. F. W. McNair before the Society for the Promotion of Engineering Education, in which he shows that the Amcrican mining schools have amply proved the necessity for their existence. From statistics of the six largest mining schools in America, he shows that the ratio of graduation to enrolment is increasing, that there is an enormous percentage increase in students enrolled, and that the mining school product is gradually taking the place of the so-called practical man. Dividing the twelve years available for comparison into three periods of four years, it is shown that the schools under consideration graduated one man to 3.6 million tons of the total mineral production during the first period, one to 10.2 millions in the second period, and one to 9.4 millions in the last period.

IN connection with the department of geography of the University of Cambridge, special public lectures will be delivered in the Michaelmas term by Sir Clements $R$. Markham, K.C.B., F.R.S., and Sir Archibald Geikie, F.R.S. The following courses, which are open to all students, whether members of the university or not, have also been arranged:-A general course in geography (with practical work) will be given by Mr. H. Yule Oldham; courses on the geography of Europe, on the principles of physical geography, and on the history of geographical discovery will also be given by Mr. Oldham. Dr. J. E. Marr, F.R.S., will lecture twice weekly on geomorphology; Dr. A. C. Haddon, F.R.S., will give courses on ethnology and on anthropogeography; and $\mathrm{Mr}$. 